\title{
THE
}

\section{Active Pacific North America Plate boundary tectonics as evidenced by seismicity in the oceanic lithosphere offshore Baja California, Mexico}

\author{
Egill Hauksson \\ Hiroo Kanamori \\ Joann Stock \\ Marie-Helene Cormier \\ University of Rhode Island, milenecormier2@gmail.com \\ Mark Legg
}

Follow this and additional works at: https://digitalcommons.uri.edu/gsofacpubs

Terms of Use

All rights reserved under copyright.

\section{Citation/Publisher Attribution}

Egill Hauksson, Hiroo Kanamori, Joann Stock, Marie-Helene Cormier, Mark Legg; Active Pacific North America Plate boundary tectonics as evidenced by seismicity in the oceanic lithosphere offshore Baja California, Mexico, Geophysical Journal International, Volume 196, Issue 3, 1 March 2014, Pages 1619-1630, https://doi.org/10.1093/gji/ggt467 Available at: https://doi.org/10.1093/gji/ggt467

This Article is brought to you for free and open access by the Graduate School of Oceanography at DigitalCommons@URI. It has been accepted for inclusion in Graduate School of Oceanography Faculty Publications by an authorized administrator of DigitalCommons@URI. For more information, please contact digitalcommons-group@uri.edu. 


\title{
Active Pacific North America Plate boundary tectonics as evidenced by seismicity in the oceanic lithosphere offshore Baja California, Mexico
}

\author{
Egill Hauksson, ${ }^{1}$ Hiroo Kanamori, ${ }^{1}$ Joann Stock, ${ }^{1}$ Marie-Helene Cormier ${ }^{2}$ \\ and Mark Legg ${ }^{3}$ \\ ${ }^{1}$ Division of Geological and Planetary Sciences, California Institute of Technology, Pasadena, CA 91125, USA. E-mail: Hauksson@caltech.edu \\ ${ }^{2}$ Department of Geological Sciences, University of Missouri, Columbia, MO 65211-1380, USA \\ ${ }^{3}$ Legg Geophysical, Huntington Beach, CA 92647, USA
}

Accepted 2013 November 15. Received 2013 November 14; in original form 2013 April 4

\begin{abstract}
SUMMAR Y
Pacific Ocean crust west of southwest North America was formed by Cenozoic seafloor spreading between the large Pacific Plate and smaller microplates. The eastern limit of this seafloor, the continent-ocean boundary, is the fossil trench along which the microplates subducted and were mostly destroyed in Miocene time. The Pacific-North America Plate boundary motion today is concentrated on continental fault systems well to the east, and this region of oceanic crust is generally thought to be within the rigid Pacific Plate. Yet, the 2012 December 14 $M_{\mathrm{w}} 6.3$ earthquake that occurred about $275 \mathrm{~km}$ west of Ensenada, Baja California, Mexico, is evidence for continued tectonism in this oceanic part of the Pacific Plate. The preferred main shock centroid depth of $20 \mathrm{~km}$ was located close to the bottom of the seismogenic thickness of the young oceanic lithosphere. The focal mechanism, derived from both teleseismic $P$-wave inversion and $W$-phase analysis of the main shock waveforms, and the 12 aftershocks of $M \sim 3-4$ are consistent with normal faulting on northeast striking nodal planes, which align with surface mapped extensional tectonic trends such as volcanic features in the region. Previous Global Positioning System (GPS) measurements on offshore islands in the California Continental Borderland had detected some distributed Pacific and North America relative plate motion strain that could extend into the epicentral region. The release of this lithospheric strain along existing zones of weakness is a more likely cause of this seismicity than current thermal contraction of the oceanic lithosphere or volcanism. The main shock caused weak to moderate ground shaking in the coastal zones of southern California, USA, and Baja California, Mexico, but the tsunami was negligible.
\end{abstract}

Key words: Earthquake source observations; Seismicity and tectonics; Transform faults; Kinematics of crustal and mantle deformation; Rheology: crust and lithosphere.

\section{INTRODUCTION}

In 2012 December an $M_{\mathrm{w}} 6.3$ earthquake occurred within oceanic lithosphere of the eastern Pacific Plate. It occurred in an unusual tectonic setting, near a fossil trench that juxtaposes Miocene oceanic lithosphere and submerged, thinned continental lithosphere of the California Continental Borderland. This region is now hundreds of kilometres away from the edge of the Pacific Plate (Fig. 1). However, it was much closer to the plate boundary earlier in its history, until subduction ceased and the continental material above the subduction zone extended as part of the evolution of the Pacific-North America Plate boundary and the transfer of continental slivers to the Pacific Plate (e.g. Nicholson et al. 1994; Bohannon \& Geist 1998).
Both global and regional seismic networks in California, USA, and Baja California, Mexico, recorded the 2012 earthquake sequence. The main shock was followed by 12 aftershocks of $M \geq 2.8$ recorded by the Caltech/USGS Southern California Seismic Network (SCSN). During the previous $80 \mathrm{yr}$, only three $M 3$ events had been recorded in the epicentral area (Fig. 2).

The effects of the main shock on populated coastal areas were minimal. The DART buoy (46412), located about $150 \mathrm{~km}$ to the north-northwest, also recorded the earthquake Rayleigh waves but the tsunami was negligible, or less than a few millimetres. More than 2860 people reported feeling the earthquake in southern California at the USGS 'did-you-feel-it' web site. The respondents described moderate shaking in Ensenada, Mexico, to weak shaking along the 

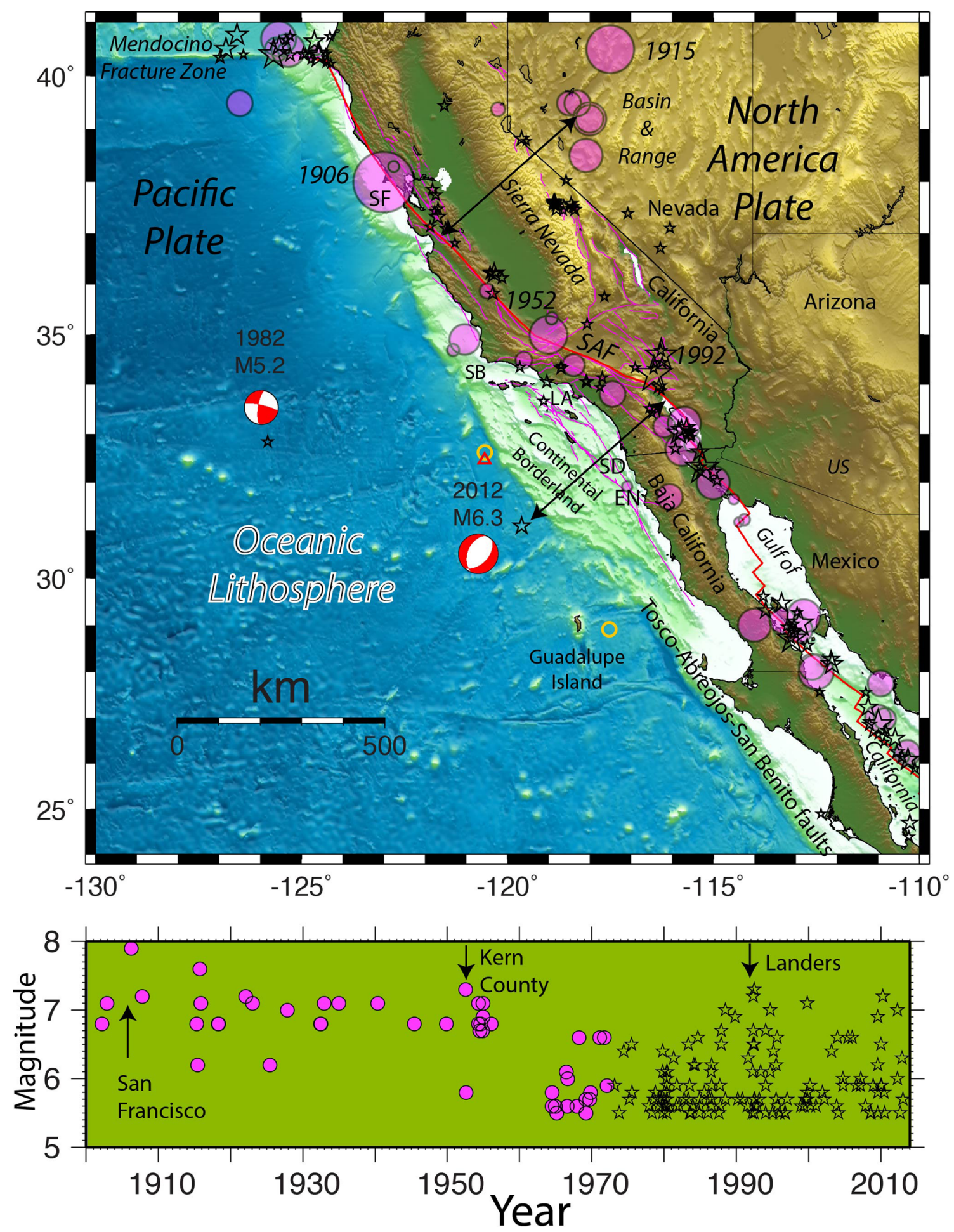

Figure 1. (Top panel) Map showing $M \geq 5.5$ epicentres in the USGS PAGER catalogue from 1900 to 1972 (pink circles), and the USGS PDE catalogue from 1973 to 2013 (black stars). Significant events are labelled with their year of occurrence. The epicentres of the 1982 and 2012 offshore main shocks are shown as stars with the lower hemisphere focal mechanism. The topography and bathymetry are from GeoMapApp, and plate boundary from Bird (2003) and California Faults are from Jennings (1994). Red triangle represents the Dart buoy; and the yellow circles Deep Sea Drilling Project holes, 469, 470 and 470A. The black double arrows are shown to compare the similar distances from the San Andreas Fault to the 2012 main shock epicentre and the seismicity on the east side of the Sierra Nevada. EN, Ensenada; LA, Los Angeles; SAF, San Andreas Fault; SB, Santa Barbara; SD, San Diego; SF, San Francisco. (Bottom panel) plot of magnitude versus date, showing events in the area covered by the map from the PAGER catalogue as pink solid circles and from the PDE catalogue as open stars. Significant events are labelled by name. 


\section{California Borderland Seismicity M 3.0: 1932 - 2013}

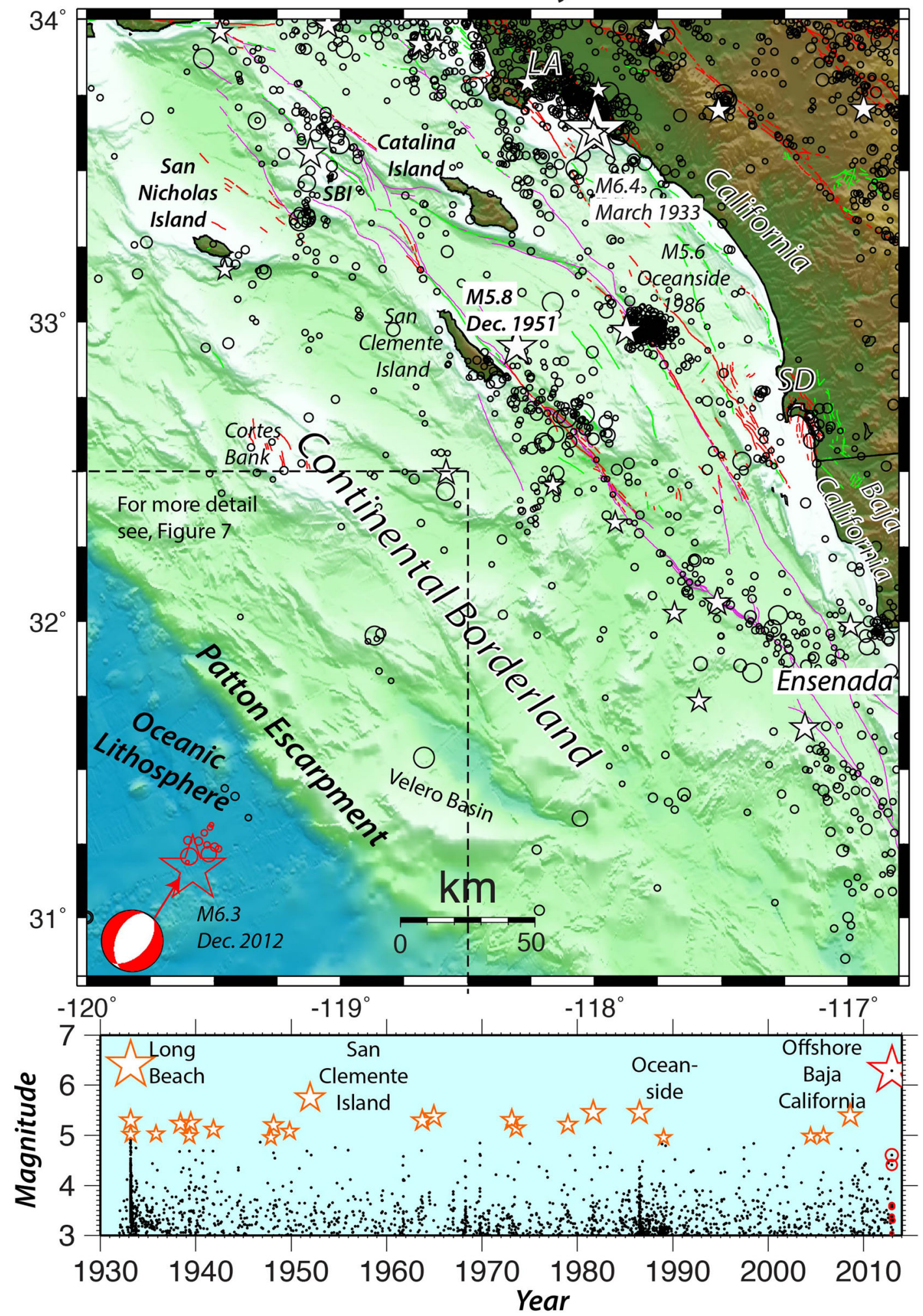

Figure 2. (Top panel) Map showing the bathymetry and topography from NGDC and GeoMapApp, SCSN $M \geq 3.0$ earthquake locations (1930-2013; Hutton et al. 2010); and the $2012 \mathrm{~W}$-phase moment tensor and relocated main shock (red star) and aftershocks (red circles). Area of Fig. 7 is indicated by dashed lines. LA, Los Angeles; SBI, Santa Barbara Island; SD, San Diego. (Bottom panel) magnitude versus date for the seismicity plotted on the map with $M \geq 5$ events shown as stars. Significant events are labeled by name. 
southern California coast, extending to Santa Barbara in the north: http://earthquake.usgs.gov/earthquakes/dyfi/events/us/c000e9sl/us/ index.html.

Shepard \& Emery (1941) were the first to document and provide explanations for northeast-trending tensional fractures in this part of the oceanic crust, offshore from California. They suggested that these fractures could be part of the northwest-tending shear, which they inferred to exist along the continental margin. Similarly, Menard (1959) provided interpretations of lowresolution bathymetric data. He was able to infer the presence of northeast-trending submarine volcanoes as has been confirmed by numerous subsequent studies (e.g. Lonsdale 1991; Davis et al. 2010).

The occurrence of the $M_{\mathrm{w}} 6.3$ earthquake within the Pacific oceanic lithosphere cannot easily be put into context of the relative Pacific-North America Plate motion, because previously the oceanic lithosphere was thought to be tectonically inactive. Immediately to the east of the epicentral area, the Continental Borderland terminates at the Patton escarpment (Fig. 2). Within the Continental Borderland, Legg et al. (2004, 2007) described the late Quaternary tectonics as dextral strike-slip faulting with both restraining bends and pull-apart basins connecting different northwest-striking fault segments. The right-lateral fault segments in the western borderland accommodate roughly 10 per cent of the relative Pacific and North America Plate motion (Beavan et al. 2002). The loading stress field associated with these locked faults in the Borderland may extend into the eastern edge of the oceanic lithosphere, and affect old zones of weakness.

\section{DATA SOURCES}

We used a variety of data sources for our study. We analysed teleseismic waveforms from various seismic networks made available through the IRIS/DMC. We compiled the topographic and bathymetric maps using data obtained from both the National Geophysical Data Center (NGDC) and GeoMapApp (Ryan et al. 2009). We obtained southern California earthquake catalogue, phase picks and waveforms from www.data.scec.org. The global moment tensors for the 1982 and 2012 events were obtained here http://www.globalcmt.org/CMTsearch.html. The global earthquake catalogue was obtained here: PAGER catalogue at http:/earthquake.usgs.gov/research/data/pager/ for 1900 through 1972. For events starting in 1973, we used the PDE catalogue found here: http:/earthquake.usgs.gov/earthquakes/eqarchives/epic/ (A. Michael, written communication, 2013). The DART ${ }^{\complement}$ buoy data were obtained from the National Center for Tsunami Research at: nctr.pmel.noaa.gov/hazard/DARTData.shtml.

\section{RESULTS}

The $2012 M_{\mathrm{w}} 6.3$ earthquake was located approximately $40 \mathrm{~km}$ west of the bathymetric step known as the Patton Escarpment (the former inner trench wall). Its location within the eastern edge of the Pacific oceanic lithosphere provides evidence for continued tectonism in a region of oceanic crust with low seismicity. The USGS global earthquake catalogue (1900-2013) contains only one other recorded earthquake of $M_{\mathrm{w}} 5.2$ (1982) within the oceanic lithosphere offshore from California and Baja California, Mexico (Fig. 1). The 1982 earthquake exhibited strike-slip faulting at a similar centroid depth of $21 \mathrm{~km}$ as the 2012 event. However, before $\sim 1965$, the catalogue is probably only complete for approximately $M \geq 6.8$ earthquakes.
It is challenging to evaluate the significance of the $2012 M_{\mathrm{W}} 6.3$ earthquake sequence because the hypocentral parameters of the sequence are not as well constrained as those for on-land sequences within the seismic network. For this location, there are no nearby (within $222 \mathrm{~km}$ distance) seismic stations. Nonetheless, because of the unusual location and the size of the main shock we have attempted to analyse available data and put this sequence in the context of both the local tectonics and the previous $80 \mathrm{yr}$ of California and Baja California, Mexico, seismicity.

Since 1900, California and Baja California seismicity has been concentrated along the San Andreas Fault zone, along transform faults in the Gulf of California, and along the eastern edge of the Sierra Nevada Microplate (Fig. 1). The two largest earthquakes both accommodate strike-slip movement: the 1906 San Francisco earthquake and the 1915 Pleasant Valley, Nevada earthquake, which occurred about $600 \mathrm{~km}$ east of the San Andreas Fault in the Basin and Range Province. The PAGER global catalogue showed steady activity of $M \sim 7$ earthquakes from 1900 to the mid-1950s. The PDE global catalogue showed that activity of $M \sim 7$ events resumed with the $M_{\mathrm{w}} 7.31992$ Landers earthquake, and has remained at the pre-1960 level since.

\subsection{Relocations of main shock and aftershocks}

We relocated the main shock and 12 aftershocks using a 3-D velocity model (Hauksson 2000) and HypoDD (Waldhauser \& Ellsworth 2000). The 3-D model is not constrained in this region but provides a way of obtaining relative relocations of the 13 earthquakes (Fig. 2). Because these earthquakes are located about $225 \mathrm{~km}$ from the nearest seismic station, and the picked phases are $P n$ or $S n$, an accurate estimate of the $P n$ velocity is important for constraining the location. We used $7.8 \mathrm{~km} \mathrm{~s}^{-1}$ from Hauksson (2000) and $8.1 \mathrm{~km} \mathrm{~s}^{-1}$ from Hearn (1984) to study the effects of possible variations in $P n$ velocities. Previously, Shor et al. (1976) obtained $P n$ velocities of $\sim 8.1 \mathrm{~km} \mathrm{~s}^{-1}$ in the outer Continental Borderland but many of their refraction profiles were not reversed. The $P n$ velocities of $7.8 \mathrm{~km} \mathrm{~s}^{-1}$ provided consistent focal depths and relative locations. The $P n$ of $8.1 \mathrm{~km} \mathrm{~s}^{-1}$ caused the epicentres to move further away from the SCSN, or about $10 \mathrm{~km}$ to the southwest, and the average focal depth became about $10 \mathrm{~km}$ deeper, which is inconsistent with the waveform-controlled centroid depth of the main shock.

When we compare the available regional and global epicentral coordinates as listed in Table 1, these are located within about $20 \mathrm{~km}$ distance, which is the expected location accuracy. Although the locations exhibit some scatter, they all lie within oceanic lithosphere of chron 5Cr(Lonsdale 1991). According to Ogg (2012) the reversed magnetic polarity isochron $5 \mathrm{Cr}$ ranges from 17.235 to $16.721 \mathrm{Ma}$, corresponding to crust of average age of $17 \mathrm{Myr}$. In comparison, the 1982 earthquake was in oceanic lithosphere that is Chron 10 age (28 Ma) or about $10 \mathrm{Myr}$ older than the lithosphere that ruptured in the 2012 earthquake.

The recording of the aftershock sequence is incomplete because there are no nearby stations. Consequently, determination of statistical parameters for the aftershock sequence such as $b$ - and $p$-values is not possible. The two largest aftershocks of M4.4 and M4.6 occurred within 14 min of the main shock, and $17 \mathrm{~s}$ of each other. The other 10 recorded aftershocks had magnitudes ranging from 2.7 to 3.6, with two aftershocks occurring in mid- to late-2013 January. The 12 aftershocks form a cluster, in the vicinity of the main shock (Fig. 2). The focal depths mostly range from 15 to $22 \mathrm{~km}$ but are 
Table 1. Source parameters for the main shock.

\begin{tabular}{lcccc}
\hline $\begin{array}{l}\text { Agency } \\
\text { ID number }\end{array}$ & $\begin{array}{c}\text { SCSN_relocated ID: } \\
\text { CI:15263753 }\end{array}$ & $\begin{array}{c}W \text {-phase, } \\
\text { this study }\end{array}$ & $\begin{array}{c}\text { USGS ID: } \\
\text { pde20121214103601590_13 }\end{array}$ & $\begin{array}{c}\text { www.globalcmt.org } \\
\text { ID: 201212141036A }\end{array}$ \\
\hline Magnitude $M_{\mathrm{w}}$ & 6.23 & 6.4 & $6.3 / 6.4$ & 6.4 \\
Latitude & 31.1643 & 31.1400 & 31.095 & 31.08 \\
Longitude & -119.582 & -119.700 & -119.660 & -119.61 \\
Depth (km) & $5^{a}$ & 19.5 & 26 & 21 \\
Strike/dip/rake: & $65 / 58 /-57$ & $45 / 48 /-73$ & $52 / 44 /-58$ & $34 / 51 /-90$ \\
first plane & & & & $(57 / 53 /-78)^{b}$ \\
Strike/dip/rake: & $194 / 44 /-131$ & $201 / 44 /-108$ & $192 / 54 /-117$ & $213 / 39 /-91$ \\
second plane & & & & $(217 / 38 /-106)^{b}$ \\
Seismic moment (Nt-m) & $2.7 \mathrm{e}+18$ & $5.0 \mathrm{e}+18$ & $5.4 \mathrm{e}+18$ & $4.5 \mathrm{e}+18$ \\
Moment tensor & -2.140 .761 .38 & -4.571 .113 .47 & -4.580 .9133 .66 & -4.030 .903 .13 \\
elements & -1.410 .451 .36 & -1.000 .212 .68 & -1.141 .722 .70 & $-0.53-0.762 .59$ \\
\hline
\end{tabular}

${ }^{a}$ Depth held fixed at $5 \mathrm{~km}$ during calculation of hypocentre.

${ }^{b}$ Fault parameters assigned or calculated for a finite fault model to confirm the centroid depth (see Fig. 6).

${ }^{c}$ The order of the moment tensor elements follows the GCMT convention with a unit of $1.0 \mathrm{e}^{+18} \mathrm{~N}-\mathrm{m}$.

poorly resolved. The number of large aftershocks is consistent with typical average southern California aftershock sequences.

\subsection{Main shock moment tensor}

Moment tensors provide the depth of the best-fit point source and a focal mechanism, and in some cases a location estimate. The SCSN automated analysis of waveforms determined the first version of the real-time SCSN moment tensor using the method of Clinton et al. (2006). This solution had an $M_{\mathrm{w}} 6.2$ and a mixed dip- and strike-slip focal mechanism but the azimuthal coverage is limited (Table 1).

To improve the estimates of the source parameters, we performed a $W$-phase inversion (Kanamori \& Rivera 2008) using 56 California Integrated Seismic Network (CISN) broad-band stations (139 channels) and 25 other stations from the Global Seismic network (GSN) and Federation of Digital Seismic Networks (FDSN; 32 channels). The period range used for inversion is from 50 to $150 \mathrm{~s}$. The relative rms of the misfit between the observed and synthetics is minimized at a depth of about $20 \mathrm{~km}$ (Fig. 3a). The irregular behaviour of the rms curve at about $24 \mathrm{~km}$ is not significant because it is caused by the velocity discontinuity at the base of the crust of the PREM model. The best-fit $W$-phase moment tensor solution has a centroid depth of $19.5 \mathrm{~km}$ (Fig. 4). In our experience with $W$-phase inversions of other earthquakes, the azimuthal coverage of $225^{\circ}$ is adequate (Kanamori \& Rivera 2008). This solution is similar to the GCMT solution, but the seismic moment of the non-double-couple component is about $\frac{1}{2}$ of that of the GCMT solution.

Because the $W$-phase code uses the PREM structure, which is different from the crustal structure near the epicentre, the depth estimate from $W$-phase inversion is somewhat uncertain. To investigate in more detail the depth of this event, we performed a teleseismic $P$-wave inversion using 48 teleseismic vertical-component $P$ waves. We used a crustal structure for the source region from Shor et al. (1976); also see Table 2. We use the method described in Kikuchi and Kanamori's software package available at (www.eri.utokyo.ac.jp/ETAL/KIKUCHI). This package contains various subroutines and inversion codes described in Kikuchi \& Kanamori (1982, 1991) and Kikuchi et al. (1993), and the particular code used in this study is similar to Hartzell \& Heaton's (1983) method. The fault plane is gridded, and the amount of slip and the time history of slip are determined at each gridpoint. The fault plane and the rupture front speed are prescribed, and the rake angle is varied within $\pm 45^{\circ}$ of the prescribed rake angle.

The best constraint on the centroid depth can be obtained by the depth phases (near-source surface reflections), but there are always trade-offs between the source waveform and depth phases. For this event, as shown in Fig. 5, the waveforms are relatively simple, and the depth phases cause a small step-wise feature on the main pulse at about $12 \mathrm{~s}$ from the onset (see also the waveforms in Fig. 6). First, we used a point source with a simple isosceles triangular source function with a half duration of $2 \mathrm{~s}$, varied the depth and computed the misfit given by the variance of the synthetic and observed waveforms. As shown in Fig. 3(b), the misfit is minimized at a depth of $20-22 \mathrm{~km}$. The waveform fit of the first cycle of the $P$ wave is visibly better for this depth range because the pulse width is matched by the depth phases (Fig. 5).

To explore further the constraints on the centroid depth, we performed a finite source inversion using a $21 \times 21 \mathrm{~km}^{2}$ fault plane with 49 gridpoints. The fault plane ( strike $=217^{\circ}$, dip $=38^{\circ}$ ) and the rupture front speed $\left(3 \mathrm{~km} \mathrm{~s}^{-1}\right)$ are prescribed. This fault plane is essentially the same as one of the nodal planes of the GCMT solution (Table 1). The source time function at each grid point consists of three isosceles triangles with a half duration of $1 \mathrm{~s}$, separated by $1 \mathrm{~s}$. The amplitudes of the triangles are determined by inversion to match the waveforms. When this much flexibility is allowed in the slip spatial distribution and time history, complex trade-off between the slip distribution and the source time function occurs. For a given starting depth, the slip is distributed over a considerable depth range with a centroid depth that is different from the starting depth. Fig. 3(b) shows the misfit as a function of the centroid depth. The misfit is minimized at a centroid depth of $19.5 \mathrm{~km}$. The broader misfit curve is a result of the trade-off between the slip distribution and the source time function. If we start with a depth larger than $22 \mathrm{~km}$, the misfit increases. In contrast, if we start with a shallow depth, say, $16 \mathrm{~km}$, then inversion puts the slip to a larger depth, with a centroid depth of $17.9 \mathrm{~km}$. Thus, the slip distribution is elongated over a large depth range from 14.3 to $21 \mathrm{~km}$. Fig. 6 shows the case for the centroid depth of $19.4 \mathrm{~km}$, which gives the best fit with a relatively compact slip distribution; the slip extends from a depth of $16.3-21.4 \mathrm{~km}$. This behaviour is consistent with that for the point source case described earlier. Choosing the conjugate nodal plane as the fault plane resulted in a slightly different solution, but the depth remained essentially the same. 

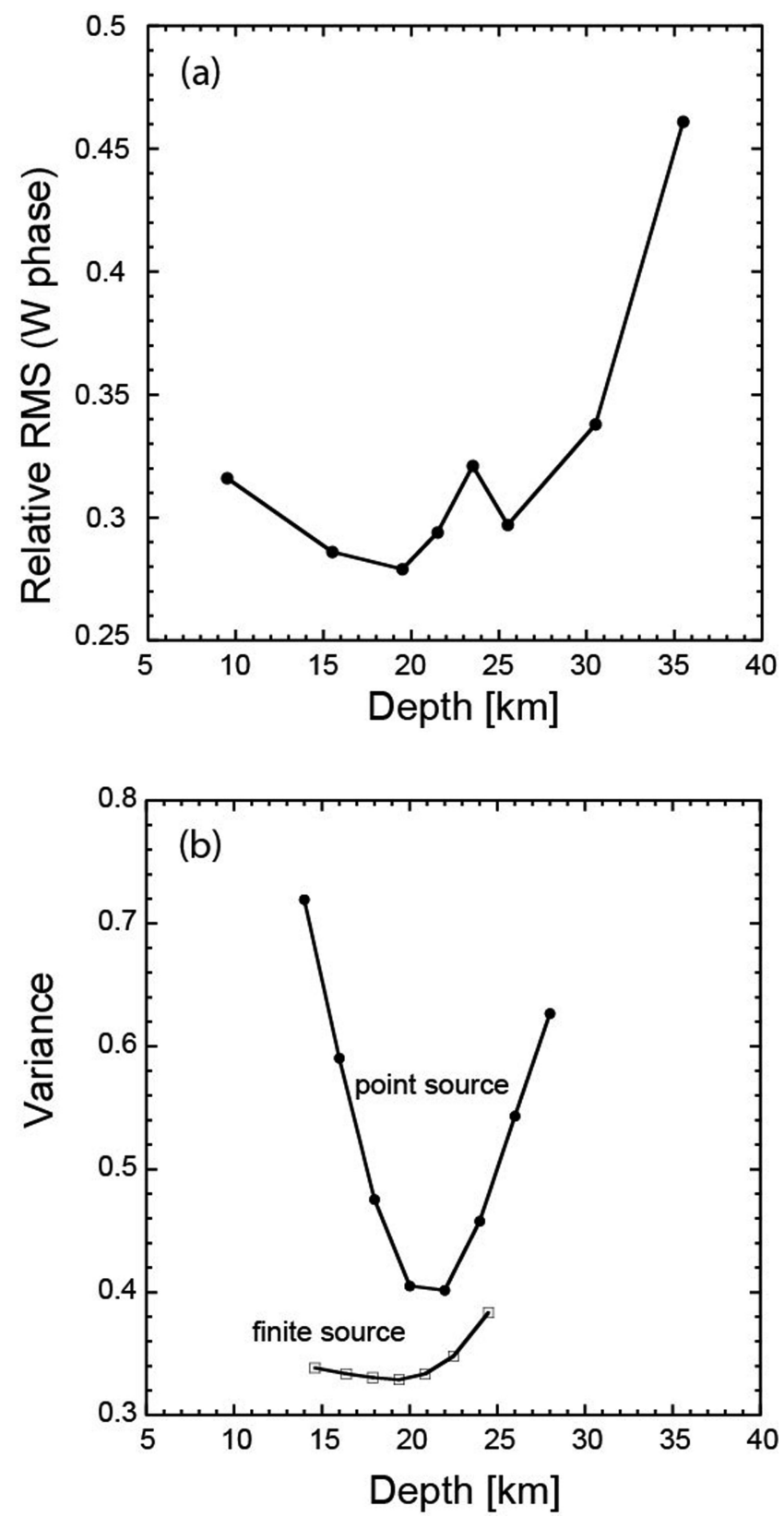

Figure 3. (a) Relative rms of the misfit between the observed and synthetic seismograms determined with the $W$-phase method. (b) The relative mean square of waveform misfit for a point source and a finite source (see text for details).

Both the USGS/NEIC and the globalcmt.org provided similar moment tensors (see also the URLs in the 'Data sources' section). The strike, dip and rake solutions from the different methods can be divided into two types, an almost pure dip-slip and a mixed dip-slip and strike-slip solution (Table 1).

\subsection{Bathymetry}

The northwest-trending Patton Escarpment defines the westernmost edge of the Continental Borderland. It is interpreted as the inner wall of a palaeotrench, similar to the one located west of southern Baja California (Michaud et al. 2004, 2007; Brothers et al. 2012).
The epicentral region is located about $35 \mathrm{~km}$ to the west, in the oceanic lithosphere of the Baja California Seamount Province.

We compiled a multibeam bathymetry map using data from 30 cruises to highlight the detailed physiography of the ocean floor within the epicentral area, 3.5-4.0 km below sea level (Fig. 7). This map clearly shows the NNW-trending fabric of the abyssal hills produced by seafloor spreading. In some places, clusters of small (100-400 m tall) circular volcanic mounds of unknown age cover the hills. Several 5- to $15-\mathrm{km}$-long volcanic ridges are also mapped, which trend north to northeast, obliquely to the dominant abyssal hill fabric (e.g. Davis et al. 2010). Similarly, magnetic anomalies formed by seafloor spreading trend about $\mathrm{N} 20^{\circ} \mathrm{W}$ and are continuous with no visible disruptions, as seen in shipboard magnetic data and the EMAG2 satellite data (Lonsdale 1991; Maus et al. 2009). In contrast, seafloor scarps with a NE orientation are not detected in either the multibeam bathymetric data or the GLORIA sidescan sonar mosaics (Paskevich et al. 2011), suggesting that these types of earthquakes are rare or too deep to have produced significant surface faulting. However, elongate NE-trending volcanic ridges, some up to $40 \mathrm{~km}$ long (Fig. 7), are consistent with extensional earthquakes during magma injection.

\subsection{Tsunami and ground shaking}

The DART buoy (46412) located $\left(32.456^{\circ} \mathrm{N}\right.$ and $\left.120.558^{\circ} \mathrm{W}\right)$ offshore from southern California recorded the main shock about 14 min after the origin time (Fig. 1). The record showed highfrequency earthquake phases that persisted for several minutes in the ocean but no tsunami was detected.

The main shock is probably too small and the centroid depth is too deep to form a scarp on the seafloor. At most there may be seafloor deformation related to strong shaking of the sediment cover in the immediate epicentral area. The recorded ground shaking, at distances exceeding $225 \mathrm{~km}$ as reported by SCSN ShakeMap, was weak. However, the did-you-feel-it maps show how the event was felt from Baja California, Mexico, in the south to Santa Barbara, California, in the north as moderate to weak shaking.

\section{DISCUSSION}

The 2012 earthquake is noteworthy for several reasons because it occurred in the oceanic lithosphere of the west flank of the East Pacific Rise. The centroid depth of about $20 \mathrm{~km}$ was close to the brittle ductile transition, and well below the oceanic Moho, which is at $\sim$ 6-7 km depth (White et al. 1992). It may define the westernmost extent of the Pacific-North America Plate motion, and thus extend the recognized source area of possible major earthquakes approximately another $100 \mathrm{~km}$ to the west. However, many other young tectonic features such as rift zones exist further offshore (Lonsdale 1991).

\subsection{Tectonic deformation of the Pacific lithosphere}

We examine several possible explanations for the 2012 oceanic lithosphere seismicity. First, it may result from the broad PacificNorth America Plate boundary tectonics. Second, thermal contraction of the cooling oceanic lithosphere may cause seismicity within the oceanic plate. Finally, we evaluate the possible role of magmatic activity. 
(a)

(b) $\quad$ wCMT, Mw $=6.40$
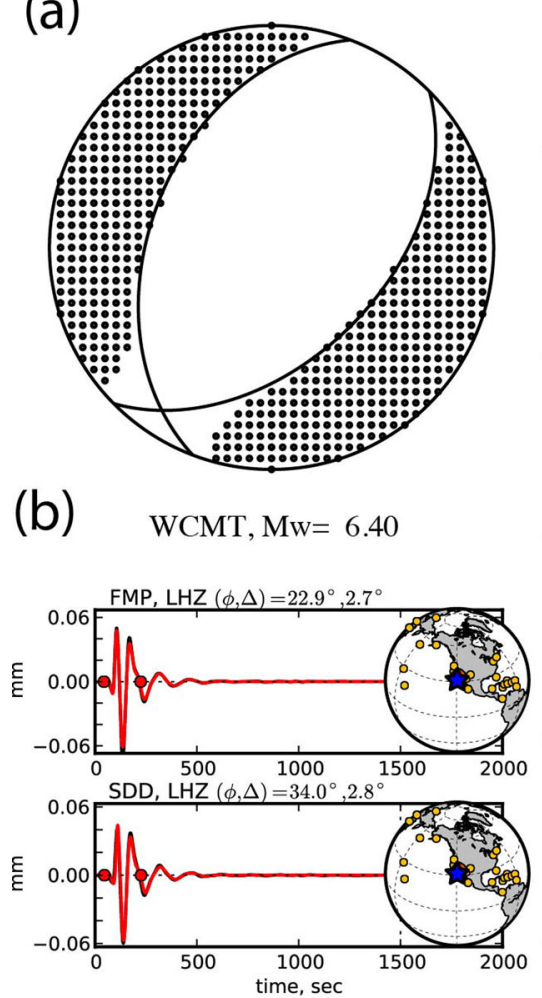

(c)
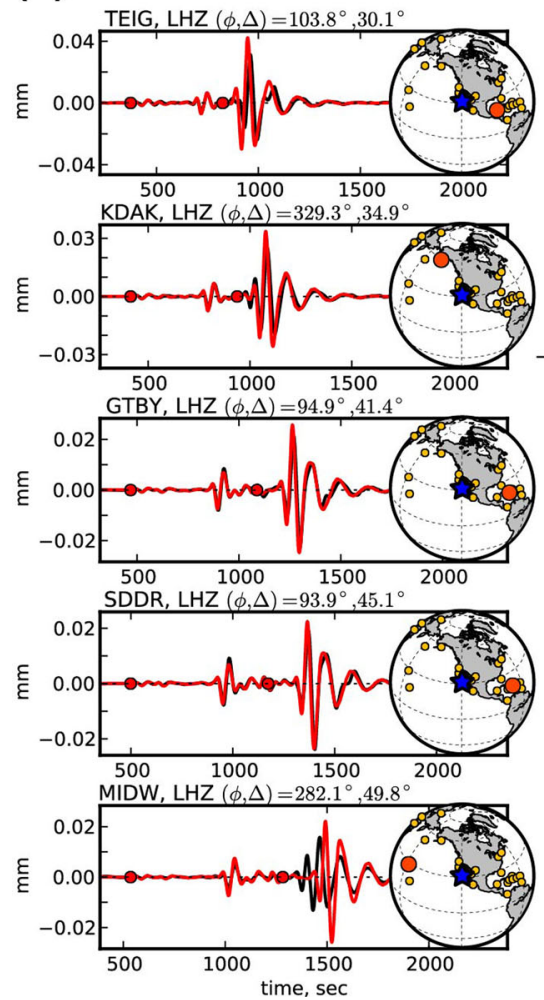
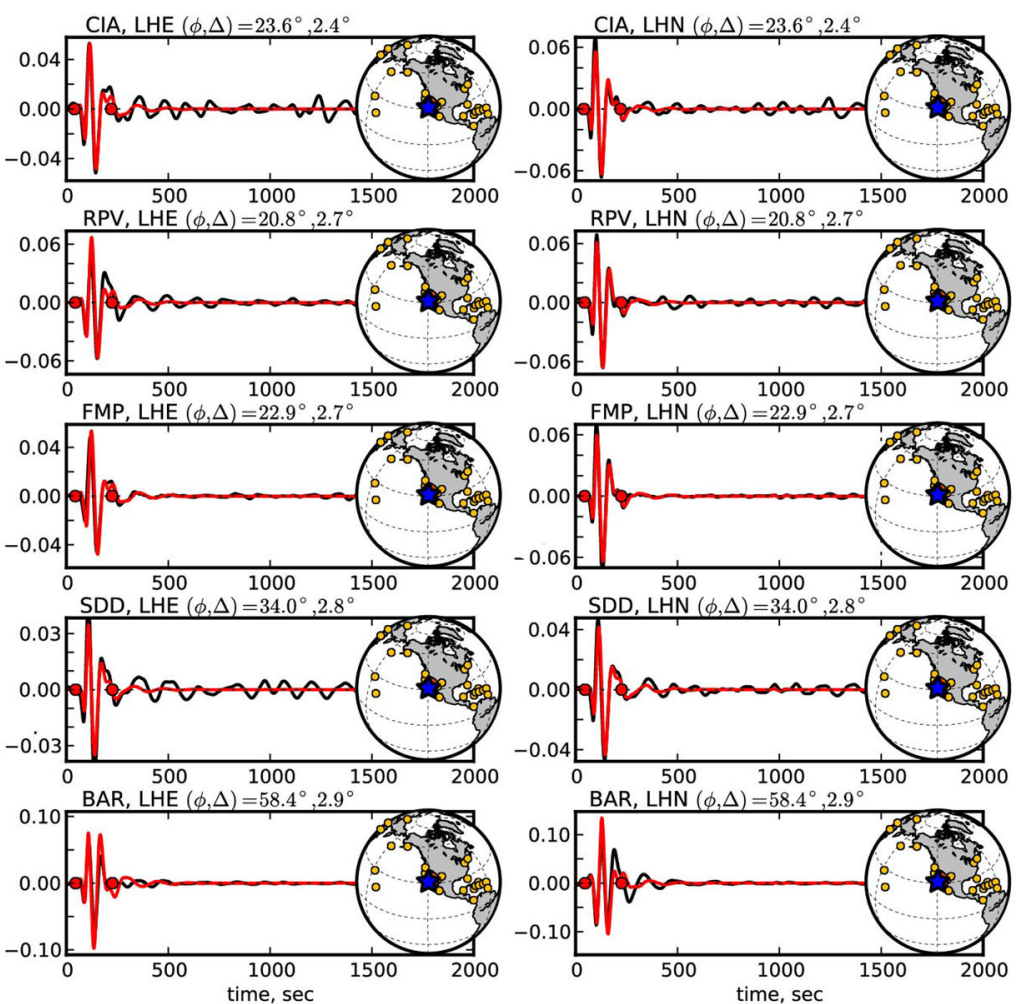
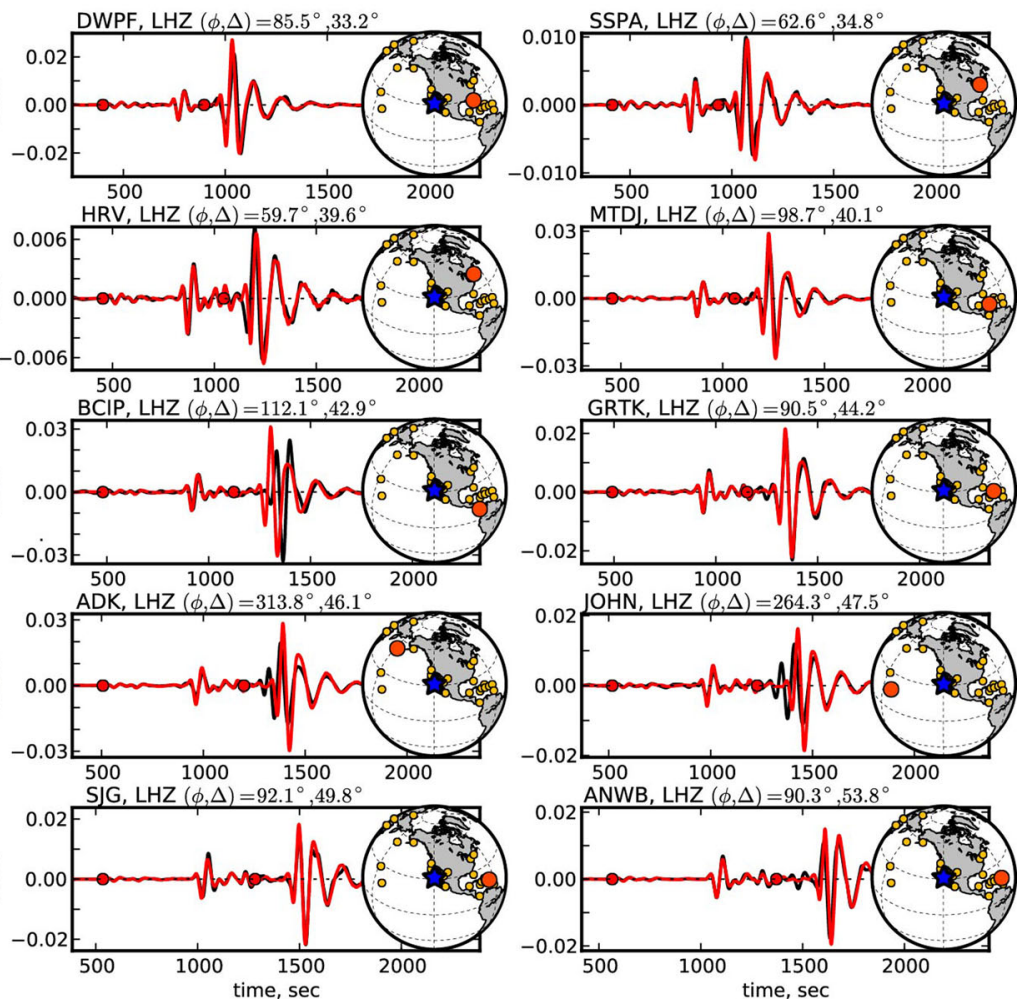

Figure 4. (a) $W$-phase moment tensor solution (WCMT) for the 2012 December earthquake, $M_{\mathrm{w}}$, centroid depth (19.5 km), strike and rake of the two nodal planes of the best double couple are listed in Table 1. (b) Sample waveforms in the azimuth range from $1.0^{\circ}$ to $58^{\circ}$ (observed: black; synthetic: red). Each trace is labelled with station code, channel, azimuth and distance in degrees. The displacement amplitude of the ground motion is given in millimetres. The two solid red circles on each trace bracket the portion of the waveform used for the inversion. The spherical map shows location of the epicentre and each station in a global scale. (c) As an example for other azimuths, we have included sample waveforms in the azimuth range from $60^{\circ}$ to $330^{\circ}$. 
Table 2. Velocity model for the source region.

\begin{tabular}{llll}
\hline Thickness $(\mathrm{km})$ & $V_{p}\left(\mathrm{~km} \mathrm{~s}^{-1}\right)$ & $V_{s}\left(\mathrm{~km} \mathrm{~s}^{-1}\right)$ & Density $\left(\mathrm{g} \mathrm{cm}^{-3}\right)$ \\
\hline 4.0 & 1.51 & 0.0 & 1.0 \\
0.1 & 2.15 & 1.45 & 2.0 \\
6.12 & 6.79 & 3.8 & 2.7 \\
- & 8.1 & 4.5 & 3.3 \\
\hline
\end{tabular}

\subsubsection{Lithospheric deformation}

Seismicity patterns indicate a broad zone of deformation associated with the Pacific-North America plate boundary. For example, the seismicity on the east side of the Sierra Nevada Microplate, and the 2012 offshore sequence, are at similar distances away from the San Andreas Fault (see black arrows in Fig. 1). The Continental Borderland and the northern Baja California Microplate that is crosscut by northwest-striking faults deform more than the stronger Sierra Microplate. However, both microplates are surrounded by seismicity extending $400-500 \mathrm{~km}$ into the adjacent plates. The $1982 M_{\mathrm{w}}$ 5.2 earthquake is located too far offshore, and probably not related to these types of plate boundary tectonic processes.

Offshore measured Global Positioning System (GPS) velocities of points on islands in the Borderland may be affected by active faults in the offshore Borderland as well as elastic strain accumulation due to San Andreas Fault motion to the east. The complex topographic relief, abundant seismicity and Holocene faulting evident in seismic reflection profiles of the Continental Borderland suggest ongoing active tectonic deformation there. Using global GPS data, Beavan et al. (2002) showed that San Nicolas Island is moving with a speed of $\sim 4 \mathrm{~mm} \mathrm{yr}^{-1}$ with respect to the rigid Pacific Plate, suggesting that there are additional active northwest-striking faults west of the island, either in the outer Continental Borderland, such as the Ferrelo and Santa Rosa-Cortes Ridge fault zones (Jennings 1994), or in the oceanic crust west of the Patton Escarpment.

These faults could be related to movement of the Baja California block within the broader plate boundary zone. This block is moving $4.3 \pm 0.8 \mathrm{~mm} \mathrm{yr}^{-1}$ slower than the Pacific Plate, due to faulting in the southern (Mexican) Continental Borderland (Plattner et al. 2007). The Tosco-Abreojos-San Benito Fault system (TAFS) forms the western margin of the central and southern Baja California Peninsula and accommodates the motion between the Baja California block and the Pacific Plate (Michaud et al. 2004). This fault structure is depicted as extending northwestward into the southern Continental Borderland and along the Patton escarpment to connect to active faults there (Fenby \& Gastil 1991) although the details of these fault connections and how they relate to the 2012 earthquake are not well understood, and interpretations vary (Legg 1991; Miller 2002; Fig. 2). Strain-loading fields adjacent to such locked faults could extend into the oceanic lithosphere and reactivate old zones of weakness, or even crosscut them; either could be the case for the fault plane that ruptured during the 2012 earthquake.

Diffuse deformation of oceanic crust has been recognized elsewhere, sometimes in regions of low seismicity. In the Indian Ocean, the slower oceanic plate boundaries are diffuse plate boundary zones, such as Capricorn-India, India-Australia, CapricornAustralia, Macquarie-Australia, Somalia-Lwandle and LwandleNubia (DeMets et al. 2010). These boundaries are characterized by slow rates of relative plate motion and may host zones of spatially diffuse seismicity. Some have such sparse seismicity that they are only recognized by statistical misfits of magnetic anomaly data across a ridge system.

The great Indian Ocean earthquakes of 2012 occurred within the fastest of these diffuse plate boundaries (e.g. Meng et al. 2012), in oceanic crust $\sim 55 \mathrm{Myr}$ in age, considerably older (and presumably stronger) than the crust of the easternmost Pacific study area discussed in this paper. Folding of the oceanic crust, and faults that cut through to the mantle, also characterize the India-Australia boundary zone (e.g. Delescluse \& Chamot-Rooke 2007). The North America-South America Plate boundary, with $<3 \mathrm{~mm} \mathrm{yr}^{-1}$ relative motion in oceanic crust of the central western Atlantic (from 0 to $140 \mathrm{Ma}$ ), has moderate earthquakes and minor deformation structures visible on the ocean floor. The Gorda zone of the Juan de Fuca Plate in the NE Pacific Ocean has ongoing diffuse deformation of young oceanic crust, as evidenced by numerous earthquakes within its interior as well as active faults that crosscut the tectonic fabric inherited from seafloor spreading (Chaytor et al. 2004). In our study area, the lithosphere is most similar in crustal age and deformation rate to the Macquarie-Australia or Capricorn-India boundaries.

\subsubsection{Thermal contraction}

A different possible cause of oceanic lithosphere seismicity is thermal contraction of juvenile oceanic lithosphere. Kumar \& Gordon (2009) showed that for a 17-Myr-old plate, such as in the epicentral region, the depth-averaged cooling rate is $\sim 14{ }^{\circ} \mathrm{C} \mathrm{Ma}^{-1}$ and the thermal contractional strain rates are on the order of $10^{-3} \mathrm{Ma}^{-1}$. However, if such strain rates caused seismicity in oceanic lithosphere, then intraplate seismicity should be more common than reported. Alternatively, non-seismic geological processes, such as aseismic creep, may accommodate such strain rates.

The presence of gravity lineaments that are an expression of the thermal contraction of the oceanic crust provides an alternative explanation of the normal faulting and deep centroid depth of the main shock. Parmentier \& Haxby (1986) modelled the thermal stresses due to the progressive, downward cooling of the oceanic

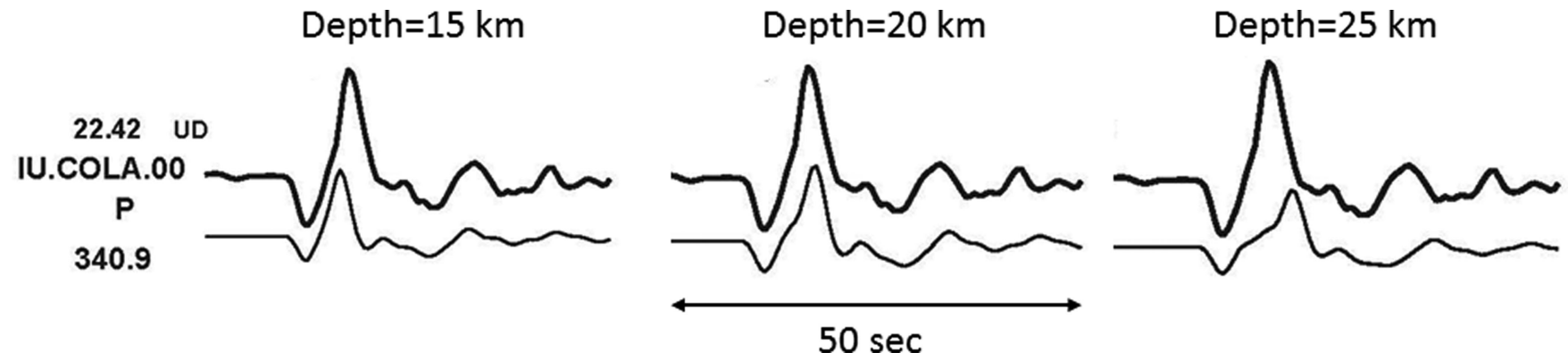

Figure 5. Sample waveforms from station: IU.COLA.00 used in the inversion (observed: heavy line; synthetics: thin line). The waveforms show trade-offs between the source waveform and depth phases for three selected depths, 15,20 and $25 \mathrm{~km}$, which cover the relevant centroid depth range. 
(a)

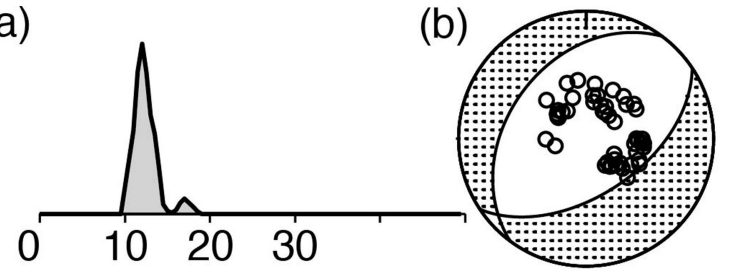

Centroid time $=3.43 \mathrm{~s}$

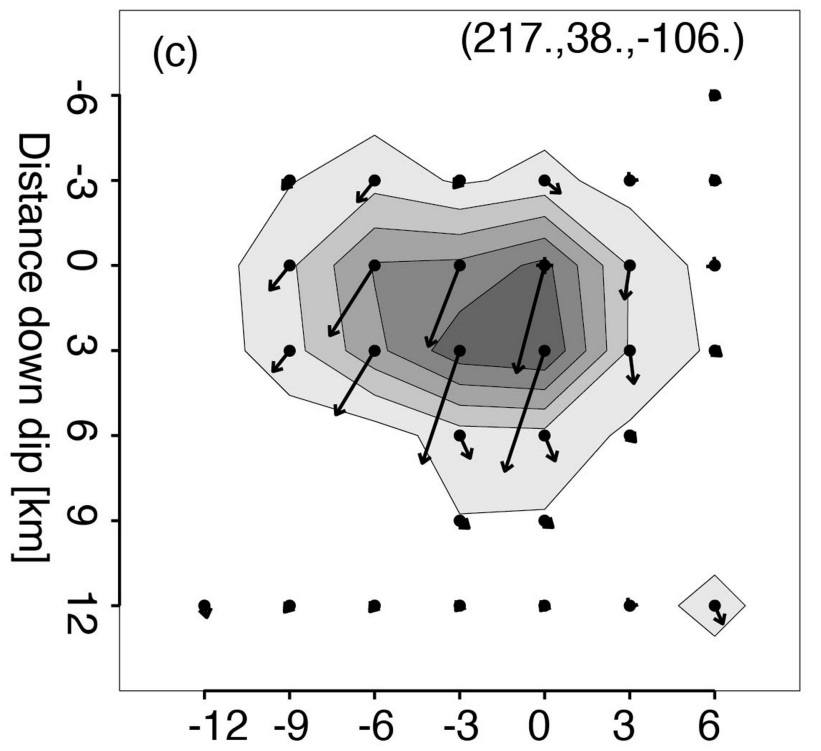

(d)

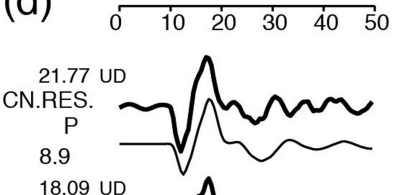

IU.KBS.00 UD

12.49 UD

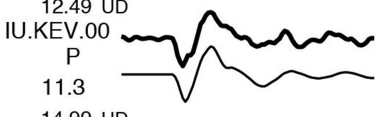

14.99 UD

GE.DAG.

14.7
14.88 UD

IU.KONO

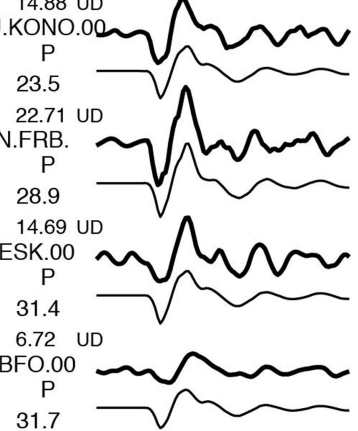

31.7
[S] $\quad 0.3287$

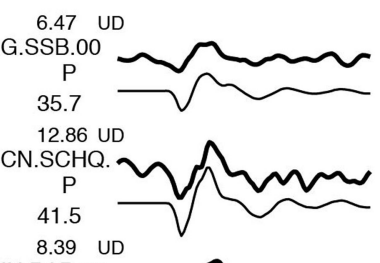

8.39 UD

IU.PAB.00 ح

${ }_{44.3}^{\mathrm{P}}$

CN.DRLN. $\sim 2$

$49.7 \longrightarrow$

14.05 UD

CN.GAC.

$\mathrm{P}$

54.1

12.85 UD

IU.MACI.

$\mathrm{P}$
59.4

59.4
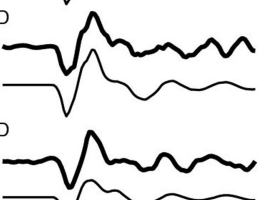

U.HRV.00

$\mathrm{P}$
59.5

9.77 UD

CU.ANWB.QQ

90.3

Distance along strike $[\mathrm{km}]$
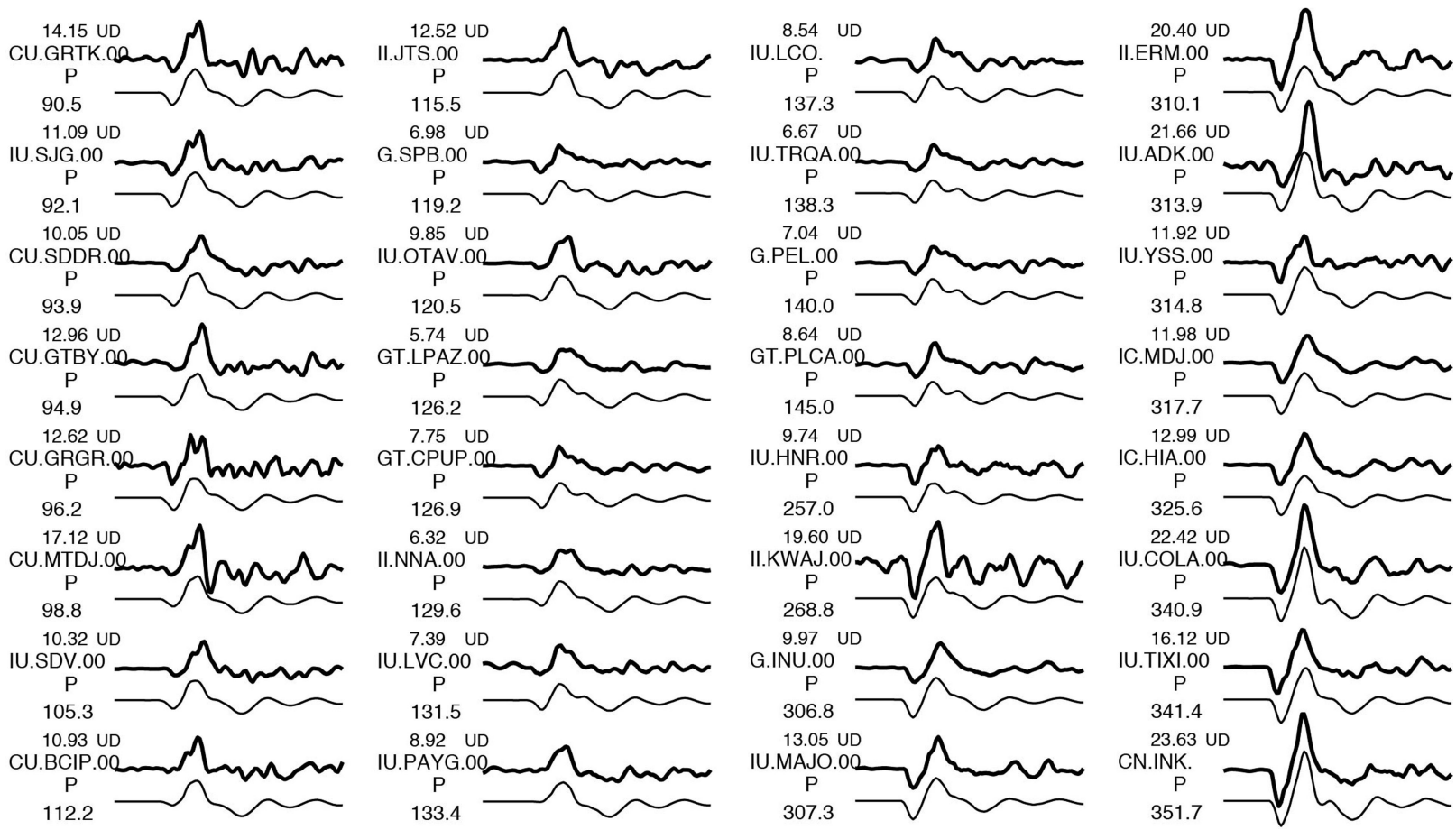

Figure 6. Teleseismic $P$-wave finite fault inversion of the $M_{\mathrm{w}} 6.3$ main shock that occurred on 2012 December 14. (a) The moment-rate function and centroid time measured from the origin time; (b) the focal mechanism indicating strike, dip and rake of the fault plane shown in (c); and (c) the slip distribution on the fault plane with slip vectors and contours in $20 \mathrm{~cm}$ intervals; the origin of the finite fault plane is at the depth of $18 \mathrm{~km}$, and positive down dip distance corresponds to increasing depth along the fault plane. (d) Sample waveforms used in the inversion (observed: heavy line; synthetics: thin line). The timescale in seconds is shown at the top right-hand side. Each trace is labelled with network and station code. The number just above the station code is the peak-to-peak amplitude of the observed waveform in micrometers, ' $P$ ' - indicates $P$-wave, and the number below the ' $P$ ' is the azimuth. 


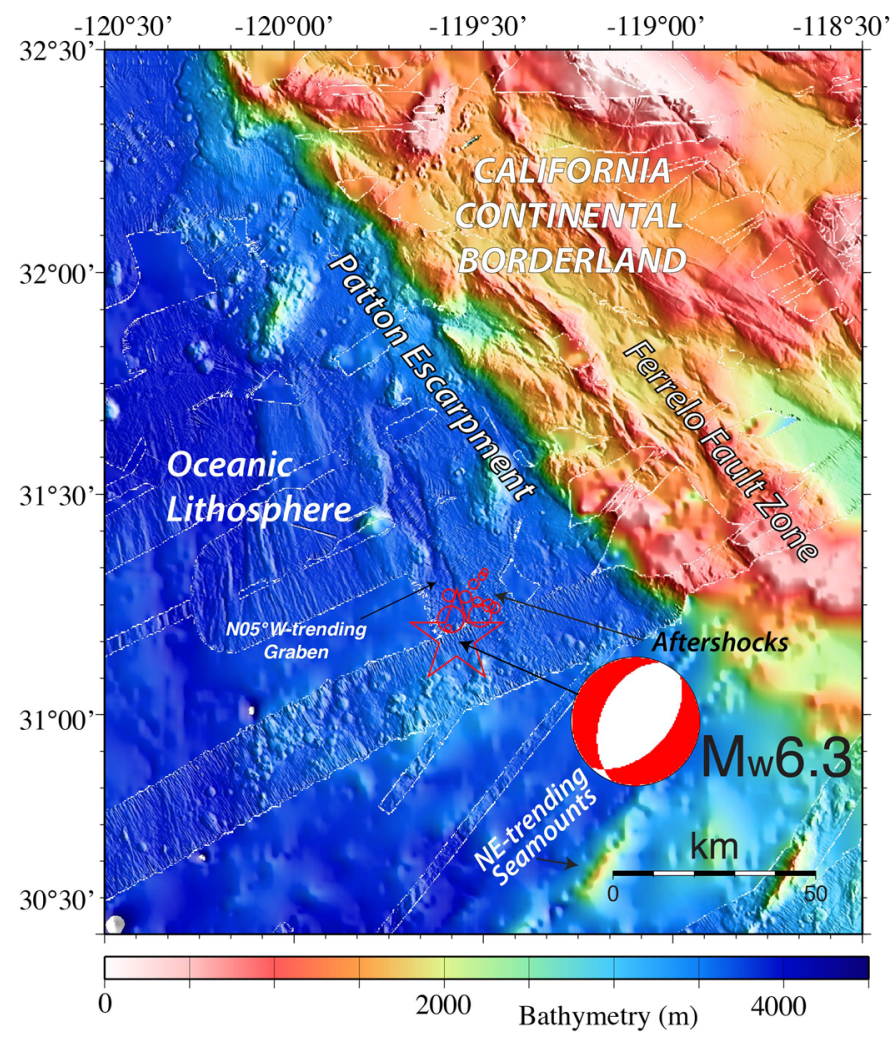

Figure 7. A close up map of the epicentral area showing multibeam bathymetric data from the NGDC and GeoMapApp, overlain on regional bathymetry, for the greater epicentral area. These data are from 30 cruises that span 1982-2011; also shown are the locations of the epicentre of the main shock (red star), lower hemisphere focal mechanism and aftershocks (red circles). N20 $\mathrm{W}$-trending oceanic crust fabric is clearly visible in the deeper water, where not covered by younger volcanic knolls. Tectonic features such as the $\mathrm{N} 5^{\circ} \mathrm{W}$-trending graben and NE-trending lineament of topographic features are labelled. Prominent northeast-trending seamounts in the area include: Northeast Bank, a late Miocene seamount in the outer Continental Borderland, located near the top centre and the linear volcanic ridges associated with the Westfall seamount chain located at the lower left-hand side.

lithosphere and predicted the development of a thermal bending moment, with tensional stresses at depth and compressional stresses near the surface. Accordingly, Gans et al. (2003) and Sandwell \& Fialko (2004) interpret lineament depressions in the central Pacific as brittle failure and the highs as convex upward flexure caused by greater cooling rate at the base of the plate. Thus, a normal faulting rupture mechanism is predicted in the lower lithosphere, and thrust in the upper lithosphere.

\subsubsection{Submarine volcanism}

The $20 \mathrm{~km}$ centroid depth of the 2012 event, and its double-couple focal mechanism, indicate that a direct relationship to seafloor magmatic activity is unlikely. Larger volcanic constructs and seamounts have been identified on oceanic crust near the base of the Patton Escarpment (Davis et al. 1995, 2002, 2010), all of which yielded Miocene ages. Davis et al. (2010) dated rock samples from a seamount $\sim 110 \mathrm{~km}$ north of the epicentral area $\left(31^{\circ} 55^{\prime} \mathrm{N}\right)$ and obtained ages of 11-14 Myr, younger than the surrounding seafloor. They inferred that the seamounts were related to the change from a subduction margin to a transform margin, suggesting that drag of North America (Baja-Borderland Microplate) on the Pacific Plate creates extension in the adjacent Pacific Plate. The volcanic constructs near the epicentral area have not been sampled or dated. The closest known Holocene volcano is Isla Guadalupe, about $250-290 \mathrm{~km}$ to the south-southeast of the epicentral area (294’N,118 $17^{\prime}$ W; Medina et al. 1989).

\subsection{Earthquake depth and style of faulting}

The 2012 main shock, at $20 \mathrm{~km}$ depth is close to the $600{ }^{\circ} \mathrm{C}$ isotherm of the 17 Myr lithospheric mantle, and thus occurred at the bottom of the seismogenic zone. The magnitude, centroid depth and the source duration of the main shock are similar to those of the 1994 $M_{\mathrm{w}} 6.7$ Northridge earthquake, which initiated at a similar depth (Hauksson et al. 1995). In particular, both events have similar impulsive teleseismic waveforms, which is consistent with the deep focal depth, although their style of faulting is opposite.

Earthquakes in oceanic lithosphere often occur below the Moho but are limited in depth by the $600{ }^{\circ} \mathrm{C}$ isotherm (McKenzie et al. 2005). These mantle earthquakes can occur in oceanic lithosphere because the seismogenic layer is slightly thicker than the elastic thickness as calculated from topography and gravity (Watts 2001). The heat flux in 17-Myr-old oceanic lithosphere is about $100 \mathrm{~mW} \mathrm{~m}^{-2}$ (McKenzie et al. 2005), which corresponds to the upper range of very seismically active areas along the Pacific and North America Plate boundary (Hauksson 2011).

\subsection{Implications for unmapped potential earthquake sources}

Both the global GPS data and the occurrence of the seismicity in 2012 suggest the presence of one or more major active faults located to the west of San Nicolas Island. Within the Continental Borderland, the Ferrelo Fault that extends from Santa Rosa Island to the south-southeast (beyond Cortes Bank and probably beyond Velero 
Basin) is one possible candidate (located in Fig. 7). Faults that extend northwestward from the San Benito-TAFS zone are other possible candidates. The faults that play a role in forming the topographic roughness of the outer Continental Borderland are likely to have very low slip rates and very infrequent major earthquakes.

There are no direct observations of northeast-striking faults within the oceanic crust. Therefore any such fault, if present, would have to have a small cumulative offset to account for the absence of obvious northeast-trending scarps, and the continuity of the magnetic anomaly patterns (Lonsdale 1991). Nevertheless, the seismicity in 2012 could be secondary faulting connected to northeaststriking fault zones that remain to be discovered.

\section{CONCLUSIONS}

The $M_{\mathrm{w}} 6.3$ earthquake of 2012 December 14 may be the largest earthquake recorded since 1900 in the eastern Pacific oceanic lithosphere, to the west of the continental shelf of the southwestern United States and Baja California, Mexico. This area was previously considered to be aseismic, and having no significant shear strain rate. Although this earthquake was located far offshore, about $225 \mathrm{~km}$ away from the nearest seismic station, it was felt in the coastal communities in southern California and Baja California, Mexico. The centroid depth of $20 \mathrm{~km}$ is close to the bottom of the seismogenic thickness of the $17 \mathrm{Myr}$ young oceanic lithosphere. The normal faulting along a NE-striking fault plane is consistent with north-northwest stretching of the Pacific Plate relative to a borderland or Baja California Microplate in the Pacific-North America Plate boundary zone. The occurrence of the 2012 seismicity suggests that the Pacific-North America Plate boundary possibly extends $400-500 \mathrm{~km}$ to the west of the San Andreas Fault system, including plate boundary deformation across the entire Continental Borderland and into the eastern edge of the oceanic Pacific Plate. Similarly distributed plate boundary deformation is also observed in northern California, with the Sierran Microplate extending the deformation $400-500 \mathrm{~km}$ away from the San Andreas Fault into Nevada.

\section{ACKNOWLEDGEMENTS}

We thank C. Sorlien and L. Jones for helpful discussions and the personnel of the USGS/Caltech SCSN and the Southern California Earthquake Data Center (SCEDC) for data collection and distribution. The IRIS DMS data center was used to access the seismic data from GSN and FDSN stations. EH was supported by NEHRP/USGS grant G13AP00047. This research was also supported by the Southern California Earthquake Center, which is funded by NSF Cooperative Agreement EAR-0529922 and USGS Cooperative Agreement 07HQAG0008. This paper is SCEC contribution \# 1745 and contribution \# 10089 of Division of Geological and Planetary Sciences, California Institute of Technology, Pasadena, CA.

\section{REFERENCES}

Beavan, J., Tregoning, P., Bevis, M., Kato, T. \& Meertens, C., 2002. Motion and rigidity of the Pacific Plate and implications for plate boundary deformation, J. geophys. Res., 107(B10), doi:10.1029/2001JB000282.

Bird, P., 2003. An updated digital model of plate boundaries, Geochem. Geophys. Geosyst., 4(3), doi:10.1029/2001GC000252.

Bohannon, R. \& Geist, E., 1998. Upper crustal structure and Neogene tectonic development of the California continental borderland, Bull. geol. Soc. Am., 110(6), 779-800.
Brothers, D. et al., 2012. Farallon slab detachment and deformation of the Magdalena Shelf, southern Baja California, Geophys. Res. Lett., 39(9), doi:10.1029/2011GL050828.

Chaytor, J.D., Goldfinger, C.D., Robert, P. \& Fox, C.G., 2004. Active deformation of the Gorda Plate: constraining deformation models with new geophysical data, Geology, 32(4), 353-356.

Clinton, J.F., Hauksson, E. \& Solanki, K., 2006. An evaluation of the SCSN moment tensor solutions: robustness of the $\mathrm{M}_{\mathrm{W}}$ magnitude scale, style of faulting, and automation of the method, Bull. seism. Soc. Am., 96(5), doi:10.1785/0120050241.

Davis, A.S., Gunn, S.H., Bohrson, W.A., Gray, L.B. \& Hein, J.R., 1995. Chemically diverse sporadic volcanism at seamounts offshore southern and Baja California, Geol. Soc. Am. Bull., 107, 554-570.

Davis, A.S., Clague, D.A., Bohrson, W.A., Dalrymple, G.B. \& Greene, H.G., 2002. Seamounts at the continental margin of California: a different kind of oceanic volcanism, Geol. Soc. Am. Bull., 114, 316-333.

Davis, A.S., Clague, D.A., Paduan, J.B., Cousens, B.L. \& Huard, J., 2010. Origin of volcanic seamounts at the continental margin of California related to changes in plate margins, Geochem. Geophys. Geosyst., 11, Q05006, doi:10.1029/2010GC003064.

Delescluse, M. \& Chamot-Rooke, N., 2007. Instantaneous deformation and kinematics of the India-Australia Plate, J. geophys. Int., 168(2), 818-842.

DeMets, C., Gordon, R.G. \& Argus, D.F., 2010. Geologically current plate motions, J. geophys. Int., 181(1), 1-80.

Fenby, S.S. \& Gastil, R.G., 1991. Geologic-tectonic map of the Gulf of California and surrounding areas, AAPG Mem., 47, 79-83.

Gans, K.D., Wilson, D.S. \& Macdonald, K.C., 2003. Pacific Plate gravity lineaments: diffuse extension or thermal contraction? Geochem. Geophys. Geosyst., 4(9), doi:10.1029/2002GC000465.

Hartzell, S. \& Heaton, T., 1983. Inversion of strong ground motion and teleseismic waveform data for the fault rupture history of the 1979 Imperial Valley, California, earthquake, Bull. seism. Soc. Am., 73, 1553-1583.

Hauksson, E., 2000. Crustal structure and seismicity distributions adjacent to the Pacific and North America plate boundary in southern California, J. geophys. Res., 105(13), 875-903.

Hauksson, E., 2011. Crustal geophysics and seismicity in southern California, J. geophys. Int., 186, 82-98.

Hauksson, E., Jones, L.M. \& Hutton, K., 1995. The 1994 Northridge earthquake sequence in California: seismological and tectonic aspects, $J$. geophys. Res., 100, 12 335-12 355.

Hearn, T.M., 1984. Pn travel times in southern California, J. geophys. Res., 89, $1843-1855$

Hutton, L.K., Woessner, J. \& Hauksson, E., 2010. Seventy-seven years (1932 -2009) of earthquake monitoring in southern California, Bull. seism. Soc. Am., 100(2), 423-446.

Jennings, C.W., 1994. Fault activity map of California and adjacent areas: with locations and ages of recent volcanic eruptions. California Department of Conservation, Division of Mines and Geology Data Map, Series No. 6, 92 p., 2 plates, map scale 1:750,000.

Kanamori, H. \& Rivera, L., 2008. Source inversion of W phase: speeding up seismic tsunami warning, J. geophys. Int., 175(1), 222-238.

Kikuchi, M. \& Kanamori, H., 1982. Inversion of complex body waves, Bull. seism. Soc. Am., 72(2), 491-506.

Kikuchi, M. \& Kanamori, H., 1991. Inversion of complex body waves: III, Bull. seism. Soc. Am., 81, 2335-2350.

Kikuchi, M., Kanamori, H. \& Satake, K., 1993. Source complexity of the 1988 Armenian earthquake: evidence for a slow after-slip event, $J$. geophys. Res., 98, 15 797-15 808.

Kumar, R.R. \& Gordon, R.G., 2009. Horizontal thermal contraction of oceanic lithosphere: the ultimate limit to the rigid plate approximation, J. geophys. Res., 114, B01403, doi:10.1029/2007JB005473.

Legg, M.R., 1991. Developments in understanding the tectonic evolution of the California Continental Borderland, SEPM, 46, 291-312 (Special Publication).

Legg, M.R., Kamerling, M.J. \& Francis, R.D., 2004. Termination of strikeslip faults at convergence zones within continental transform boundaries: examples from the California Continental Borderland, Geol. (Lond.) Soc. Spec. Publ., 227, 65-82. 
Legg, M.R., Goldfinger, C., Kamerling, M.J., Chaytor, J.D. \& Einstein, D.E., 2007. Morphology, structure and evolution of California Continental Borderland restraining bends, Geol. Soc. (Lond.) Spec. Publ., 290, 143168.

Lonsdale, P., 1991. Structural patterns of the Pacific floor offshore of Peninsular California, AAPG Mem., 47, 87-125.

Maus, S. et al. 2009. EMAG2: a 2-arc min resolution earth magnetic anomaly grid compiled from satellite, airborne, and marine magnetic measurements, Geochem. Geophys. Geosyst., 10(8), Q08005, doi:10.1029/2009GC002471.

McKenzie, D., Jackson, J. \& Priestley, K., 2005. Thermal structure of oceanic and continental lithosphere, Earth planet. Sci. Lett., 233, 337- 349.

Medina, F., Suárez, V.F. \& Espíndola, J.M., 1989. Historic and Holocene volcanic centers in NW Mexico, Bull. Volcanol., 51(Suppl. 1), 9193.

Menard, H.W., 1959. Minor lineations in the Pacific Basin, Bull. geol. Soc. Am., 70, 1491-1496.

Meng, L., Ampuero, J.-P., Stock, J., Duputel, Z., Luo, Y. \& Tsai, V.C., 2012. Earthquake in a maze: compressional rupture branching during the 2012 $M_{\mathrm{w}}$ 8.6 Sumatra earthquake, Science, 337(6095), 724-726.

Michaud, F. et al. 2004. Motion partitioning between the Pacific plate, Baja California and the North America plate: the Tosco-Abreojos fault revisited, Geophys. Res. Lett., 31, L08604, doi:10.1029/2004GL019665.

Michaud, F. et al., 2007. Right-lateral active faulting between southern Baja California and the Pacific plate: the Tosco-Abreojos fault, Geol. Soc. Am. Spec. Papers, 422, 287-300.

Miller, K.C., 2002. Geophysical evidence for Miocene extension and mafic magmatic addition in the California Continental Borderland, Bull. geol. Soc. Am., 114(4), 497-512.

Nicholson, C., Sorlien, C.C., Atwater, T., Crowell, J.C. \& Luyendyk, B.P., 1994. Microplate capture, rotation of the western Transverse Ranges, and initiation of the San Andreas transform as a low-angle fault system, Geology, 22(6), 491-495.
Ogg, J.C., 2012. Geomagnetic polarity time scale, in The Geologic Time Scale 2012, pp. 85-113, Vol. 1, eds Gradstein, F.M., Ogg, J.G., Schmitz, M.D. \& Ogg, G.M. Elsevier.

Parmentier, E.M. \& Haxby, W.F., 1986. Thermal stresses in the oceanic lithosphere: evidence from geoid anomalies at fracture zones, J. geophys. Res., 91, 7193-7204.

Paskevich, V.F., Wong, F.L., O’Malley, J.J., Stevenson, A.J. \& Gutmacher, C.E., 2011. GLORIA sidescan-sonar imagery for parts of the U.S. Exclusive Economic Zone and adjacent areas. Open-File Rep, U.S. Geol. Surv., 2010-1332.

Plattner, C., Malservisi, R., Dixon, T.H., LaFemina, P., Sella, G., Fletcher, F.J. \& Suarez-Vidal, F., 2007. New constraints on relative motion between the Pacific Plate and Baja California microplate (Mexico) from GPS measurements, J. geophys. Int., 170, 1373-1380.

Ryan, W.B.F. et al., 2009. Global multi-resolution topography synthesis, Geochem. Geophys. Geosyst., 10, Q03014, doi:10.1029/2008GC002332.

Sandwell, D. \& Fialko, Y., 2004. Warping and cracking of the Pacific plate by thermal contraction, J. geophys. Res., 109, B10411, doi:10.1029/2004JB003091.

Shepard, F.P. \& Emery, K.O., 1941. Submarine Topography off the California Coast: canyons and tectonic interpretation, Geol. Soc. Am., Special Paper no. 31, $171 \mathrm{p}$.

Shor, G.G., Raitt, R.W., Jr, \& McGowan, D.D., 1976. Seismic Refraction Studies in The Southern California Borderland, 1949-1974, SIO Reference 76-13. Scripps Institution of Oceanography.

Waldhauser, F. \& Ellsworth, W.L., 2000. A double-difference earthquake location algorithm: method and application to the northern Hayward Fault, California, Bull. seism. Soc. Am., 90, 1353-1368.

Watts, A.B., 2001. Isostasy and Flexure of the Lithosphere. Cambridge Univ. Press.

White, R.S., McKenzie, D. \& O’Nions, R.K. 1992. Oceanic crustal thickness from seismic measurements and rare earth element inversions, J. geophys. Res., 97, 19 683-19 715. 